Imalat Teknolojileri ve Uygulamalarl

Cilt: 2, No: 3, 2021 (34-46)

Derleme Makale

e-ISSN: 2717-7475
Manufacturing Technologies and Applications

Vol: 2, Issue: 3, 2021 (34-46)

Review Article

e-ISSN: 2717-7475

\title{
Tool Wear in Machining of Wrought and Cast Aluminium Alloys: Literature Review
}

Cem ALPARSLAN ${ }^{1, *}$ iD, Şenol BAYRAKTAR ${ }^{1}$ iD

${ }^{I}$ Recep Tayyip Erdoğan Üniversitesi, Mühendislik ve Mimarlık Fakültesi, 53100, Rize, Türkiye

\section{MAKALE BILGISI}

Alınma: 11.10.2021

Kabul: 30.11 .2021

Anahtar Kelimeler:

Aluminum alloys

Machinability

Cutting force

Surface roughness

Tool wear

\begin{abstract}
Aluminum and its alloys are commonly used in industry due to their lightness, high strength/weight ratio and easy formability. Various machining operations such as turning, drilling, milling and threading are needed in order to be manufactured in desired forms and used as a final product in mechanical systems. However, some problems arise that negatively affect the machined surface quality, dimensional tolerance and cutting tool (CT) performance during the machining of these materials. CT wear is among the most important of these problems. CT wear also causes loss of time due to tool changing and machine tool adjustment requirements in machining operations. In this study, current studies on tool wear in the cutting of aluminum-based alloys were investigated in detail and the factors affecting tool wear were presented comparatively.
\end{abstract}

\section{Dövme ve Döküm Alüminyum Alaşımlarının İşılenmesinde Takım Aşınması: Literatür Araștırması}

\section{ARTICLE INFO}

Received: 11.10 .2021

Accepted: 30.11 .2021

Keywords:

Alüminyum alaşımları

İşlenebilirlik

Kesme kuvveti

Yüzey pürüzlülüğü

Takım aşınması

\section{ÖZET}

Alüminyum ve alaşımları hafiflik, yüksek mukavemet/ağırlık oranı ve kolay şekillendirilebilme özelliklerinden dolayı endüstride yaygın kullanım alanına sahiptir. İstenilen formlarda üretilebilmesi ve mekanik sistemlerde nihai ürün olarak kullanılabilmeleri için tornalama, delme, frezeleme ve diş açma gibi farklı işleme operasyonlarına ihtiyaç duyulmaktadır. Ancak, bu malzemelerin işlenmesi esnasında işlenmiş yüzey kalitesini, boyutsal toleransı ve kesici takım performansını olumsuz etkileyen bazı sorunlar ortaya çıkmaktadır. Kesici takım aşınması, bu sorunlardan en önemlileri arasında yer almaktadır. Kesici takım aşınması, işleme operasyonlarında takım değiştirme ve takım tezgâhı ayarlama gereksinimlerinden dolayı zaman kaybına da yol açmaktadır. Bu çalışmada, literatürde alüminyum esaslı alaşımların işlenmesinde takım aşınması üzerine yapılan güncel çalışmalar detaylı bir şekilde araştırılmış ve takım aşınması üzerinde etkili olan faktörler karşılaştırmalı olarak ortaya konulmuştur.

\section{INTRODUCTION (GIRIŞ)}

Aluminum alloys are an important material today due to their high strength/weight ratio, lightness, corrosion resistance, thermal and electrical conductivity. This situation increases the widespread use of aluminum alloys in the industry, depending on the developing technology [1]. It is preferred in aerospace, automotive, medical and defense industries due to its properties [2-5]. In addition, structural and mechanical properties can be developed by adding alloying elements such as copper, manganese, zinc, magnesium and silicon to aluminum-based alloys [6]. Thus, efficient results can be obtained with longer service life in mechanical systems. These alloys are subjected to different conventional machining operations such as turning, milling and drilling in line with consumer needs so that they can be used as structural elements in mechanical systems. Since it has different structural properties, it exhibits different properties in the machining method. Cutting speed $\left(V_{\mathrm{c}}\right)$, feed rate $(f)$ and depth of cut $\left(a_{\mathrm{p}}\right)$ are defined as machinability input variables, while output variables are cutting force $\left(\mathrm{F}_{\mathrm{c}}\right)$, surface roughness $(\mathrm{Ra})$ and tool wear $(\mathrm{TW})$ during the machining of materials. Aluminum alloys exhibit a tendency to stick due to the adhesion wear 
mechanism in the CT during the cutting process with the effect of high ductility. This tendency brings about an increase in the Fc and a reduce in the machined surface quality [7]. Accordingly, independent variables such as $V_{c}, f, a_{p}$, CT material and coolant must be controlled in order to minimize tool wear which is among the machining outputs [8,9]. In this study, current studies in the literature about the effects of these independent variables on TW during cutting of aluminumbased alloys were investigated in detail and presented in a comparative way.

\section{CUTTING TOOL WEAR MECHANISMS (KESICI TAKIM AŞINMA MEKANIZMALARI)}

TW is one of the most significant factor showing the machinability index of materials. Minimum tool wear is a necessary criterion for maximum productivity in machining theory. Different CT materials and coatings can be preferred for machining aluminum alloys. Among these, high-strength diamond and diamond-coated tools provide a better tool life and a good surface quality [10]. However, diamond and diamond-coated tools are expensive compared to other tools. Coated/uncoated carbide tools cost less than diamond tools. Efficient results can be obtained in the cutting of aluminum-based alloys in terms of cost criteria. HSS (High speed steel) CTs can also be used for roughing machining operations. TW that occurs during machining in CTs reveals with the effect of deformations [11]. TW is a tribological feature that causes an increase in Ra in the area where the CT contacts, due to the effect of the machining mechanism [12]. Surface quality is a factor that affects tool life, dimensional tolerance of the machined material and the economy of the machining process. Many types of wear can occur in CTs during the cutting of aluminum-based materials. Some of these wear types are flank, crater, notch wear, built up edge (BUE), built up layer (BUL) and thermal crack. Flank wear is formed on the surface of the CT where it comes into contact with the machined material. It is formed by the continuous friction of the worn area on the machined surface. It causes excessive wear on the CTs depending on time (Fig. 1a) [13]. Notch wear is the result of excessive localized damage on both the bevel surface and the flank surface of the insert at the $a_{\mathrm{p}}$ line. It occurs due to the hardened surface structure with adhesion and deformation. It is particularly common in the machining of stainless steel materials (Fig. 1b) [14]. BUE occurs when ductile materials are machined at low $V_{\mathrm{c}}$. It causes a change in cutting edge geometry (Fig. 1c) [15]. Crater wear occurs when high-temperature chips strike the CT surface. Crater wear is known to result from diffusion or dissolution wear at high $V_{\mathrm{c}}$. In other words, it occurs due to the effect of the chemical reaction between the workpiece and the CT (Fig. 1d) [16]. Thermal crack occurs with the effect of sudden increase and decrease in tool-chip temperatures during material machining. It usually occurs with interrupted cutting and the use of coolant in milling (Fig. 1e) [17].
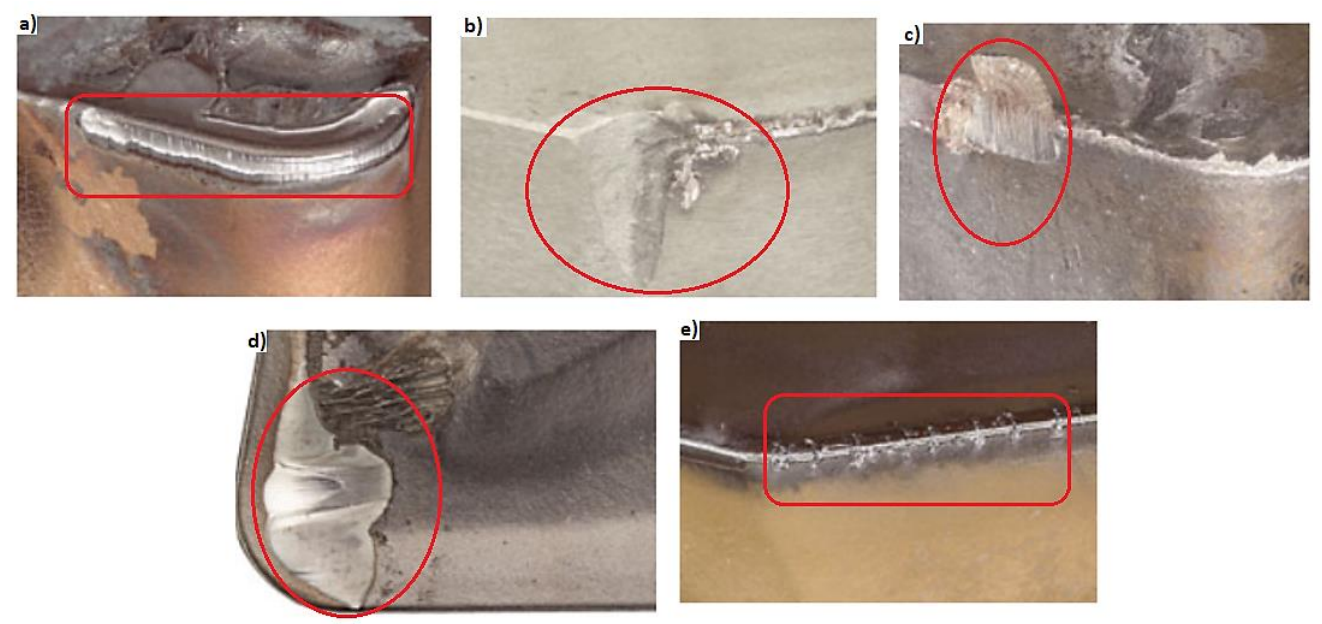

Figure 1. Wear mechanisms on the CT, a) Flank wear, b) Notch wear, c) BUE, d) Crater wear and e) Thermal crack [18]

(Kesici takımdaki aşınma mekanizmaları, a) Serbest yüzey aşınması, b) Çentik aşınması, c) Yığıntı talaş, d) Krater aşınması ve e) Termal çatlak)

\footnotetext{
* Sorumlu yazarın e-posta adresi: cem.alparslan@erdogan.edu.tr
}

https://doi.org/10.52795/mateca.1008145 


\section{TOOL WEAR IN MACHINING OF ALUMINIUM-BASED ALLOYS (ALÜMINYUM ESASLI ALAŞIMLARIN IŞ̧LENMESINDE TAKIM AŞINMASI)}

Aluminum alloys are divided into two groups as wrought and cast. In addition, it can be categorized according to the properties of alloying elements such as strain-hardenable and heattreated alloys. The machinability of many wrought aluminum alloys is excellent. While cast alloys containing zinc, magnesium and copper as main alloying elements cause machining difficulties, the use of small tool rake angle has been found to improve machinability. Alloys containing silicon as the main alloying element require the use of large rake angle, low speed and feed, which increases the cost [19].

\subsection{Wrought Aluminium Alloys (Dövme Alüminyum Alaşımları)}

Wrought aluminum alloys are ideal for applications where a lighter metal is needed for performance and safety, speed or energy efficiency. Aluminum wheels on racing cars and bodies of aircraft are a perfect example of this. It has low density compared to steel. It is an ideal material for aviation applications. In addition, wrought alloys can be easily shaped due to their good plastic deformation ability. Examining the outputs obtained in the machining of these alloys is very important in terms of the performance of these alloys. It has been determined that many studies have been done on tool wear related to wrought alloys in the literature. Ping et al. were investigated surface integrity and tool wear using different $V_{\mathrm{c}}(250$ and $750 \mathrm{~m} / \mathrm{min}), f(0.06$ and $0.08 \mathrm{~mm} /$ tooth $)$ and $a_{\mathrm{p}}(0.5$ and 1.5 $\mathrm{mm}$ ) in milling of 7050-T7451 aluminum alloy. It was observed that as the $V_{\mathrm{c}}$ increased, the Fc, Ra and BUE decreased. It was determined that the Ra increased with the increase of BUE formation on the machined surface at low $V_{\mathrm{c}}$. In addition, it was revealed that the formation of BUE increased with increasing of $f$ [20]. Gao et al. researched the wear behavior of tungsten-carbide (WC) grain size and cobalt $(\mathrm{Co})$ content on the $\mathrm{CT}$ in the micro-milling process of 7075 aluminum alloy. They used constant $V_{\mathrm{c}}$ of $20 \mathrm{~m} / \mathrm{min}, f$ of $2 \mu \mathrm{m}$ and $a_{\mathrm{p}}$ of $50 \mu \mathrm{m}$ parameters. It was observed that the end mill with finer grain size exhibited better wear resistance and the end teeth flank wear length of the micro end mill increased with the increase of WC grain size. It was also revealed that the micro end mill exhibits less wear resistance with the increase of Co content (Fig. 2) [21].
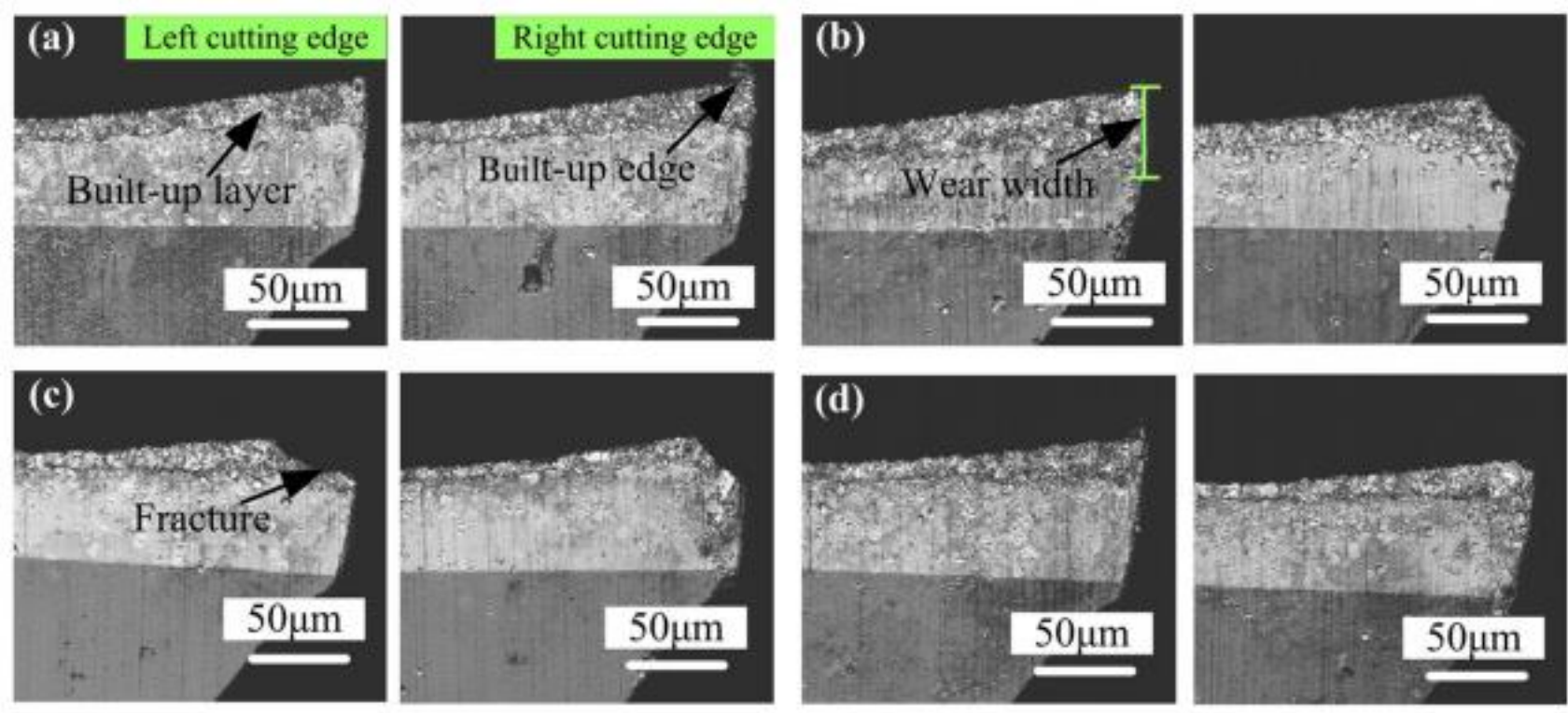

Figure 2. Wear morphologies on micro end mills for machining length of $480 \mathrm{~mm}$, a) K55SF, b) DK500UF, c)

DK450UF and d) DK120UF [21] (480 mm işleme uzunluğu için mikro parmak frezelerde aşınma morfolojileri)

\footnotetext{
* Sorumlu yazarin e-posta adresi: cem.alparslan@erdogan.edu.tr https://doi.org/10.52795/mateca.1008145
} 
Wang et al. were examined TW in micro-milling of Al-6061 alloy diameter of $1 \mathrm{~mm}$ and TiAlN coated carbide tool. Different radial $a_{\mathrm{p}}(100,200$ and $300 \mu \mathrm{m})$, axial $a_{\mathrm{p}}(100,150$ and $200 \mu \mathrm{m})$ and feed per tooth $(1,2$ and $3 \mu \mathrm{m} /$ tooth) parameters were used. The order of importance and optimum values for the independent variable parameters were determined as axial $a_{\mathrm{p}}: 300 \mu \mathrm{m}$, feed per tooth: $1 \mu \mathrm{m}$ and radial $a_{\mathrm{p}}: 150 \mu \mathrm{m}$, respectively. While it was observed that the main wear forms were coating peeling (Fig. 3a), tool tip breakage (Fig. 3b) and adhesive (Fig. 3c) was detected as the wear mechanism [22].

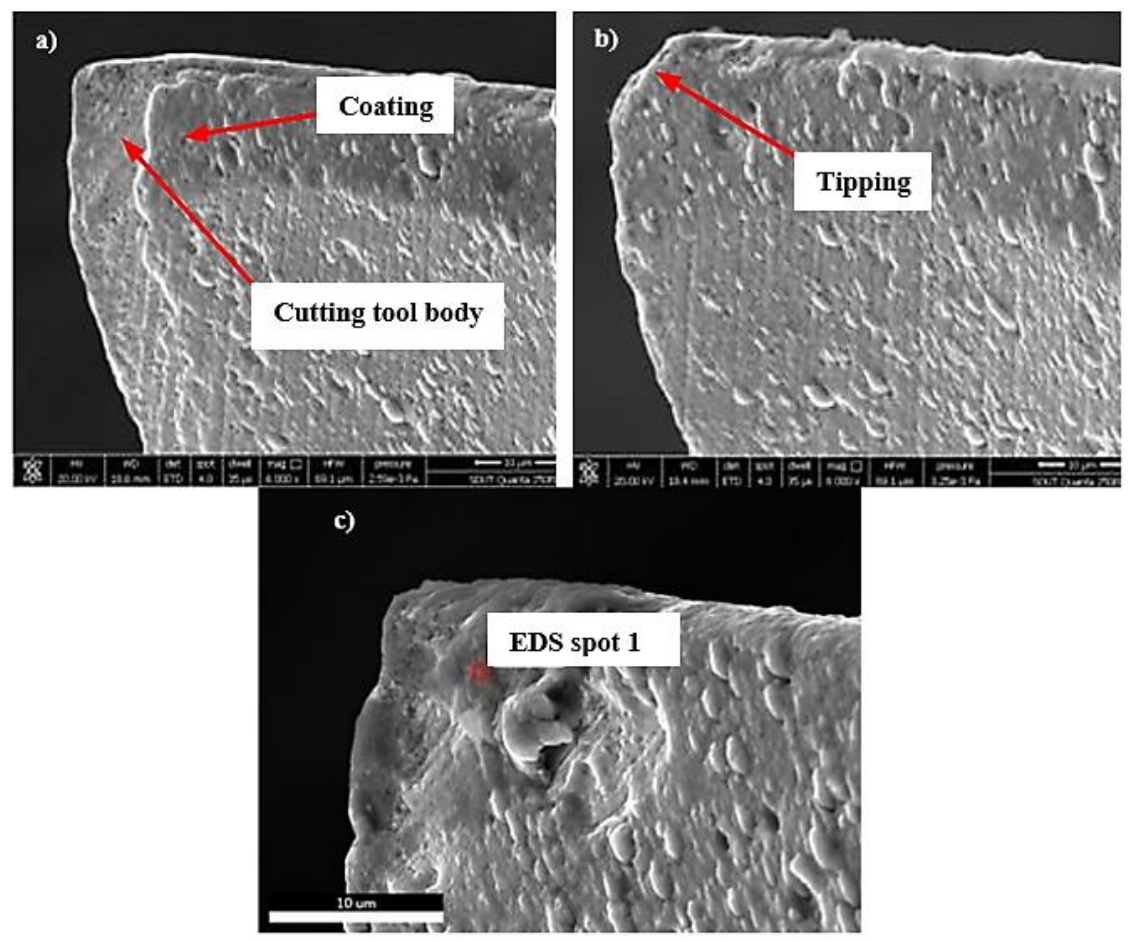

Figure 3. SEM (Scanning electron microscope) and EDS (Energy dispersive X-ray spectroscopy) images on TiAlN coated tool wear, a) Coating peeling, b) Breakage near edge nose of tool and c) Adhesive wear on tool [22] (TiAlN kaplamalı takımda takım aşınması görüntüleri, a) Kaplama soyulması, b) Takımın kenar ucuna yakın kırılma ve c) Takımda adhesiv aşınma)

Zhang et al. researched the wear behavior of CTs during ultrasonic elliptical vibration cutting (UEVC) and conventional cutting (CC) of Al-7055-T7451 alloy. TW was investigated using different $V_{\mathrm{c}}(600,900,1200,1500$ and $1800 \mathrm{~m} / \mathrm{min}), a_{\mathrm{p}}(1.5 ; 2 ; 2.5 ; 3$ and $3.5 \mathrm{~mm})$, feed $(0.025$, $0.05,0.075,0.1$ and $0.125 \mathrm{~mm} / \mathrm{z})$ and vibration frequencies $(5000,10000,15000,20000$ and 25000 $\mathrm{Hz}$ ). It was observed that obtained under the same cutting parameters approximately four times better surface quality with UEVC. Microcracks and large adhesion areas were observed on the machined surface using $\mathrm{CC}$, while better surface quality was observed using UEVC. It was determined that tool wear was 3-5 times higher in $\mathrm{CC}$ under the same cutting parameters. While tipping, spalling wear, adhesive and oxidative wear occurred as tool wear in CC, mild adhesive and abrasive wear was observed in UEVC (Fig. 4) [23]. 


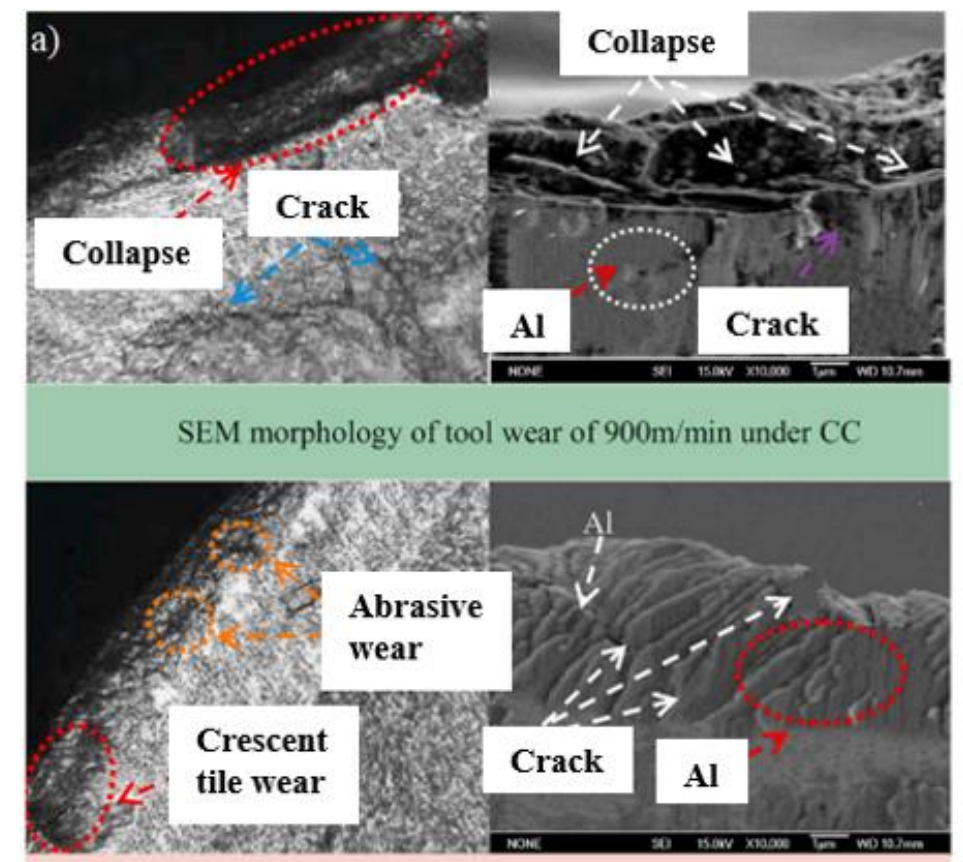

SEM morphology of tool wear of $900 \mathrm{~m} / \mathrm{min}$ under UEVCC

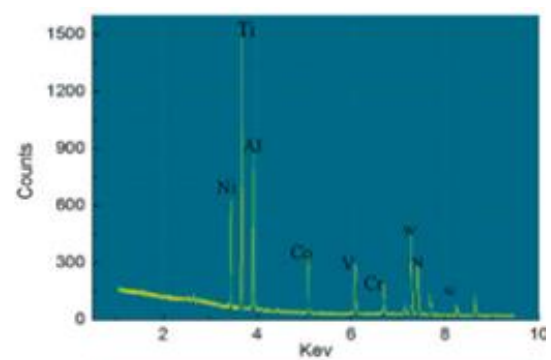

EDS of $900 \mathrm{~m} / \mathrm{min}$ under $\mathrm{CC}$

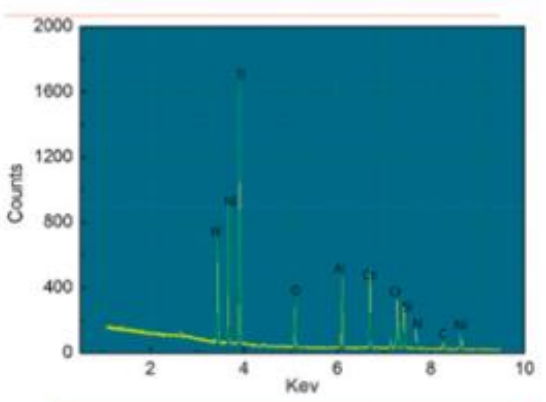

EDS of $900 \mathrm{~m} / \mathrm{min}$ under UEVC

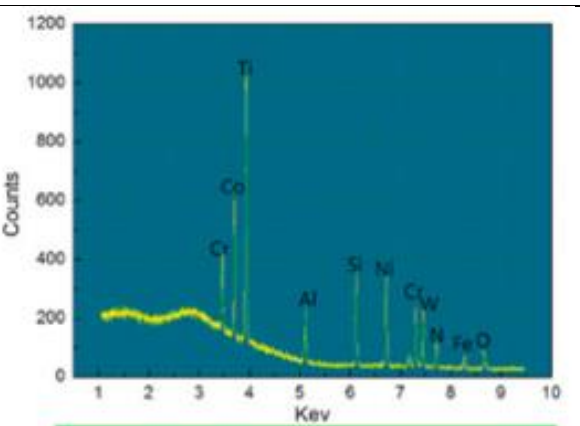

EDS of $2.5 \mathrm{~mm}$ under $\mathrm{CC}$

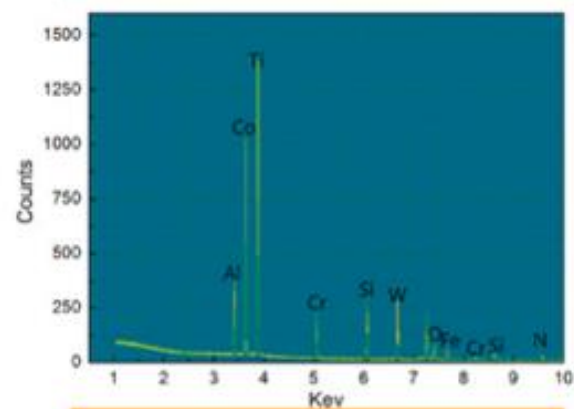

EDS of $2.5 \mathrm{~mm}$ under UEVC

SEM morphology of tool wear of $2.5 \mathrm{~mm}$ under UEVC

Figure 4. Tool wear in CC and UEVC, a) SEM and EDS tool wear images for $900 \mathrm{~m} / \mathrm{min}$ and b) SEM and EDS tool wear images for $a_{\mathrm{p}}$ of $2.5 \mathrm{~mm}$ [23] (CC ve UEVC'de takım aşınması, a) $900 \mathrm{~m} /$ dak için SEM ve EDS takım aşınma görüntüleri ve b) $2,5 \mathrm{~mm}$ kesme derinliği için SEM ve EDS takım aşınma görüntüleri)

\subsection{Cast Aluminium Alloys (Döküm Alüminyum Alaşımları)}

The use of light alloys in mechanical systems causes weak tribological properties. Different alloying elements can be added to improve the tribological properties in the casting technique. Thus, cast aluminum alloys can be widely used in the manufacture of engine blocks and bearing

\footnotetext{
* Sorumlu yazarin e-posta adresi: cem.alparslan@erdogan.edu.tr https://doi.org/10.52795/mateca.1008145
} 
materials in the automotive sector. However, machining processes are required for cast alloys to be used as final products in mechanical systems. Workpieces machined in the appropriate tolerance ranges can be used precisely in mechanical systems. It has been observed that current studies on this subject have been done in the literature. Bayraktar and Afyon examined the impacts of $\mathrm{Zn}$ and $\mathrm{Cu}$ additions on the thrust force, $\mathrm{Ra}$ and tool wear of the Al-7Si alloy manufactured by the permanent mold casting method. Constant $V_{\mathrm{c}}(120 \mathrm{~m} / \mathrm{min}), f(0.15 \mathrm{~mm} / \mathrm{rev})$, depth of cut $(15 \mathrm{~mm})$ and uncoated carbide drills were used for drilling tests. While the minimum thrust force and Ra were determined in the drilling of $\mathrm{Al}-7 \mathrm{Si}-4 \mathrm{Zn}-3 \mathrm{Cu}$ alloy (Fig. 5c), maximum BUE formation was observed in the drilling of Al-7Si (Fig. 5a) and Al-7Si-4Zn alloy (Fig. 5b) [24].
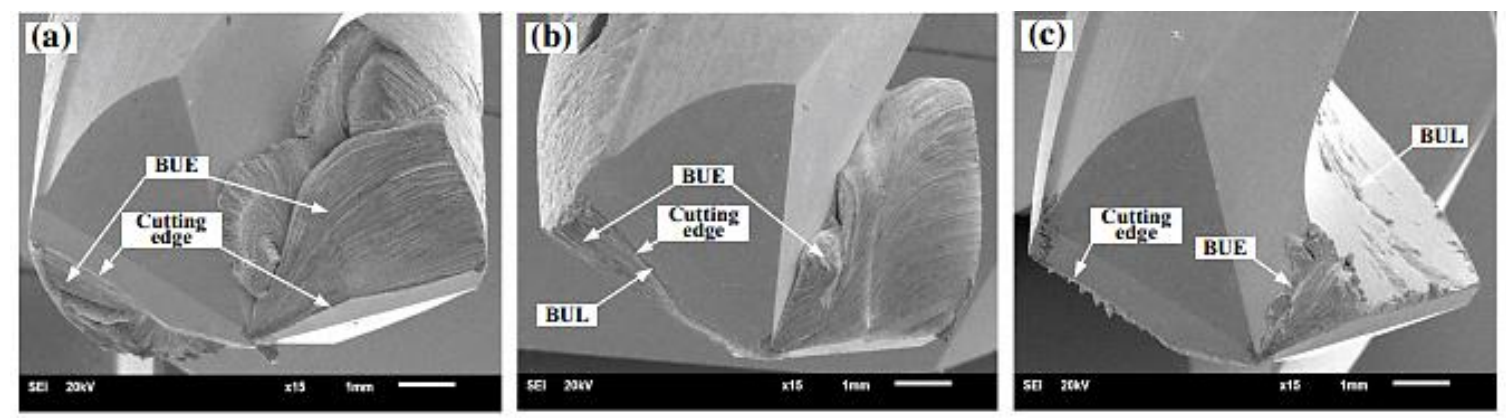

Figure 5. BUE ve BUL formation on the drills, a) Al-7Si, b) Al-7Si-4Zn and c) Al-7Si-4Zn-3Cu [24] (Matkaplarda yığıntı talaş ve yığıntı katman oluşumu)

Hekimoğlu et al. researched the Fc, Ra and TW in the milling of Al-35Zn alloy manufactured by the permanent mold casting method. The experiments were carried out at different $V_{c}(600,1200$, $1800 \mathrm{rpm})$, feed $(0.05 ; 0.1$ and $0.15 \mathrm{~mm} /$ tooth $)$ and constant $a_{\mathrm{p}}(1.5 \mathrm{~mm})$ using uncoated and TiAlN coated carbide end mills. The Fc, Ra, BUE and BUL decreased with the increasing of $V_{\mathrm{c}}$ in both CTs, while it increased with the increasing of $f$. It was found that uncoated carbide tools outperformed in terms of Fc, Ra and tool TW (Fig. 6) [25].
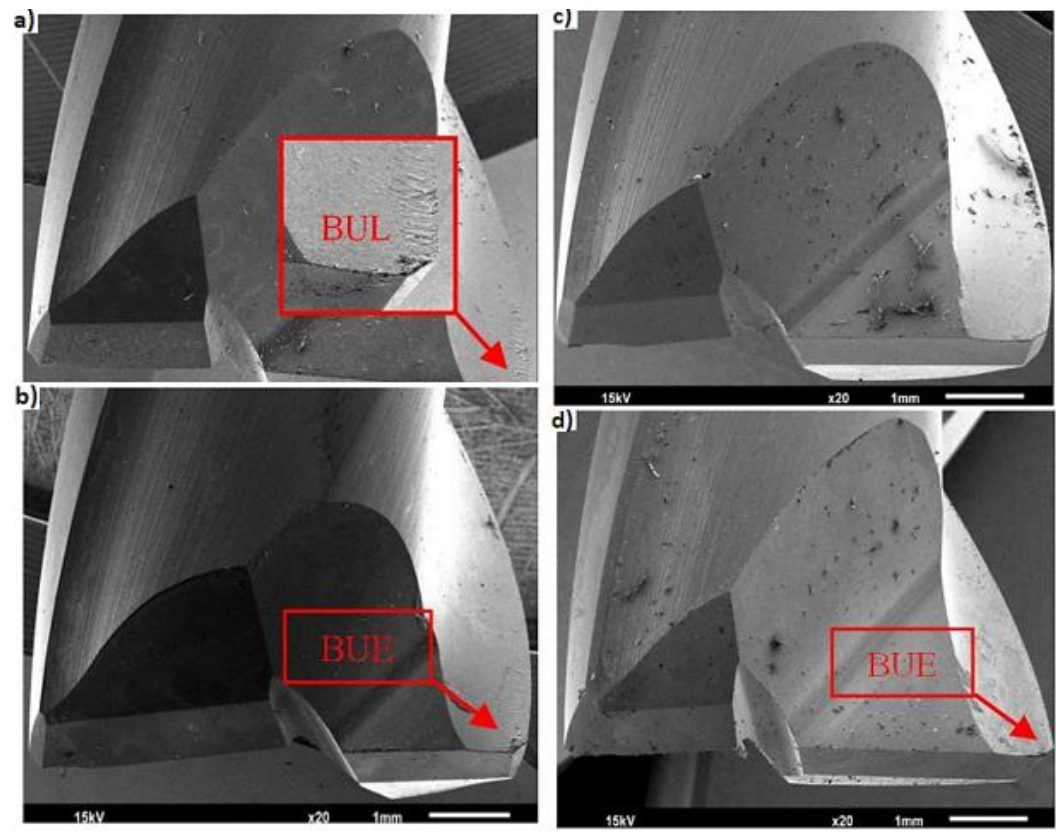

Figure 6. Wear on the CT edge, a) Wear on TiAlN coated tool for $\left.V_{\mathrm{c}}: 600 \mathrm{rev} / \mathrm{min}, f: 0.05 \mathrm{~mm} / \mathrm{tooth}\right)$, b) Wear on

TiAlN coated tool for $\left.V_{\mathrm{c}}: 1800 \mathrm{rev} / \mathrm{min}, f: 0.15 \mathrm{~mm} / \mathrm{tooth}\right)$, c) Wear on uncoated tool for $V_{\mathrm{c}}: 600 \mathrm{rev} / \mathrm{min}, f: 0.05$ $\mathrm{mm} /$ tooth) and d) Wear on uncoated tool for $V_{\mathrm{c}}: 1800 \mathrm{rev} / \mathrm{min}, f: 0.15 \mathrm{~mm} /$ tooth) [25] (Kesici takımda aşınma, a) $V_{\mathrm{c}}: 600$ dev/dak ve $f: 0,05 \mathrm{~mm} /$ diş için TiAlN kaplamalı takımda aşınma, b) $V_{\mathrm{c}}: 1800$ dev/dak ve $f: 0,15 \mathrm{~mm} /$ diş için TiAlN kaplamalı takımda aşınma, c) $V_{\mathrm{c}}: 600$ dev/dak ve $f: 0,05 \mathrm{~mm} /$ diş için kaplamasız takımda aşınma ve d) $V_{\mathrm{c}}: 1800 \mathrm{dev} / \mathrm{dak}$ ve $f: 0,15 \mathrm{~mm} /$ diş için kaplamasız takımda aşınma) 
Bayraktar et al. examined the impacts of $\mathrm{Cu}$ and $\mathrm{Si}$ additions on $\mathrm{Fc}, \mathrm{Ra}$ and tool wear in $\mathrm{Al}-25 \mathrm{Zn}$ alloy manufactured by permanent mold casting method. Different $V_{\mathrm{c}}(250,350$ and $450 \mathrm{~m} / \mathrm{min}), f$ (0.05; 0.1 and $0.15 \mathrm{~mm} / \mathrm{rev})$, constant $a_{\mathrm{p}}(1.5 \mathrm{~mm})$ and $\mathrm{CVD}-\mathrm{Al}_{2} \mathrm{O}_{3}$ coated carbide insert were used in the experiments. It was revealed that while the Fc and Ra decrease with increasing of $V_{\mathrm{c}}$, they increase with increase of $f$. While $\mathrm{Fc}$ and $\mathrm{Ra}$ increased with the addition of $\mathrm{Si}$, they decreased with the addition of $\mathrm{Cu}$. The least BUE formation was determined under $\mathrm{Cu}$ addition, $450 \mathrm{~m} / \mathrm{min} V_{\mathrm{c}}$ and $0.05 \mathrm{~mm} / \mathrm{rev}$ feed conditions (Fig. 7) [26].
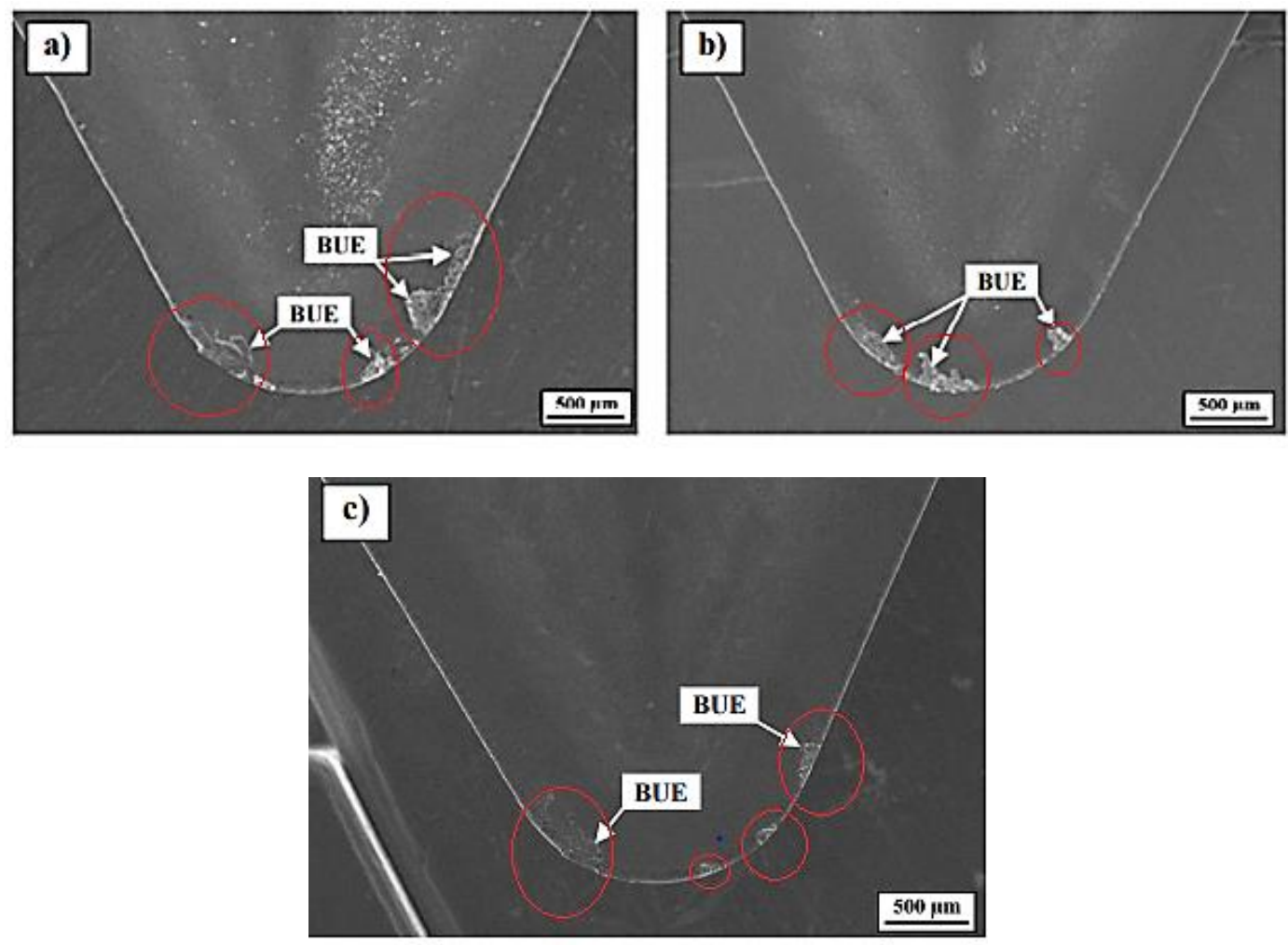

Figure 7. BUE formations at the different $V_{\mathrm{c}}$ values for Al-25Zn-3Cu alloy, a) $250 \mathrm{~m} / \mathrm{min}$, b) $350 \mathrm{~m} / \mathrm{min}$ and c) 450 $\mathrm{m} / \mathrm{min}$ [26] (Al-25Zn-3Cu alaşımı için farklı kesme hızı değerlerinde yığıntı talaş oluşumları)

Ghoreishi et al. examined TW in high speed face milling of $\mathrm{Al} / \mathrm{SiC}$ metal matrix composites using different $V_{\mathrm{c}}(1000-2500 \mathrm{~m} / \mathrm{min}), f(0.01-0.1 \mathrm{~mm} /$ tooth $), a_{\mathrm{p}}(0.25-2 \mathrm{~mm})$ and coolant (Dry and $\mathrm{CO}_{2}$ ). It was observed that the tool wear rate increased more than 2.5 times with the increase of $V_{\mathrm{c}}$ from $1000 \mathrm{~m} / \mathrm{min}$ to $2500 \mathrm{~m} / \mathrm{min}$. In addition, it was revealed that the tool wear rate increased five times with an increasing of $a_{\mathrm{p}}$ from $0.25 \mathrm{~mm}$ to $2 \mathrm{~mm}$, while the tool wear rate increased eight times with an increasing of $f$ from $0.01 \mathrm{~mm} /$ tooth to $0.1 \mathrm{~mm} /$ tooth [27]. Pul investigated effects of different $\mathrm{MgO}$ reinforcement ratios (5, 10 and 15\%) on tool wear and Ra during the turning of Al$\mathrm{MgO}$ metal matrix composite materials with carbide $(\mathrm{C})$, cubic boron nitride $(\mathrm{CBN})$ and coated cubic boron nitride (CBNC) CTs. For this, different $V_{\mathrm{c}}(150,200,250$ and $300 \mathrm{~m} / \mathrm{min}), f(0.075$, 0.15 and $0.225 \mathrm{~mm} / \mathrm{rev})$ and constant $a_{\mathrm{p}}(1 \mathrm{~mm})$ were used. It was determined that while the Ra values decreased with the increasing of $V_{\mathrm{c}}$, it increased with the increasing of $f$. It was observed that the highest Ra values were measured at a $V_{\mathrm{c}}$ of $150 \mathrm{~m} / \mathrm{min}$ and a $f$ of $0.225 \mathrm{~mm} / \mathrm{rev}$. It was revealed that BUE and abrasive wear mechanism were effective in all CTs and ideal results were obtained with $\mathrm{C}$ tools and $10 \%$ reinforcement ratio (Fig. 8) [28].

Recently, many researches have been carried out on tool wear during machining of wrought and casting aluminum alloys. General information about these studies were given in Table 1. 

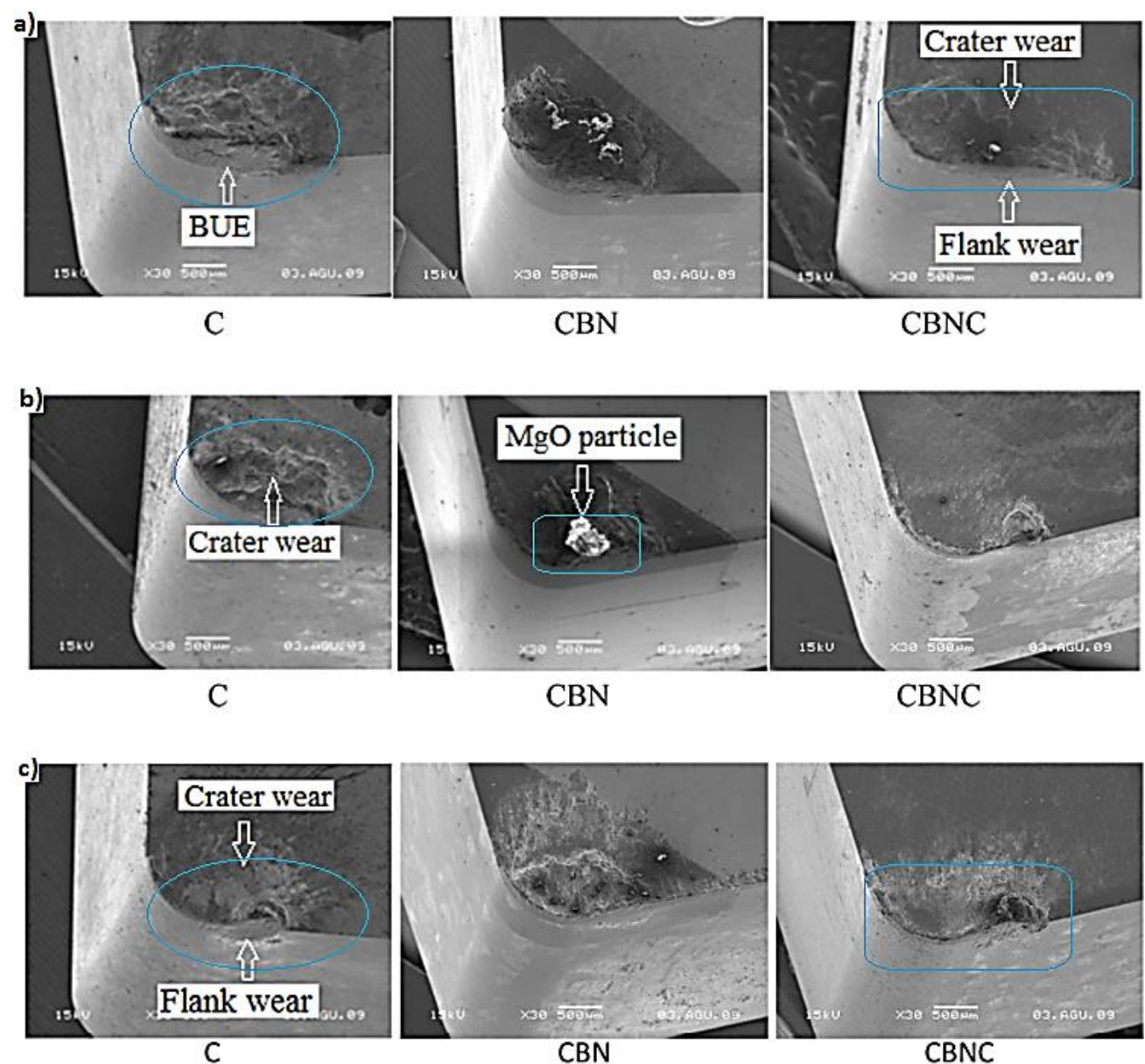

Figure 8. Tool wear images for $\mathrm{C}, \mathrm{CBN}$ and $\mathrm{CBNC}$ tool materials in different reinforced rates, a) $\% 5 \mathrm{MgO}$, b) $\% 10$ $\mathrm{MgO}$ and c) \%15 MgO [28] (Farklı takviye oranlarında C, CBN ve CBNC kesici takım malzemeleri için takım aşınma görüntüleri) 
Table 1. Literature researches on tool wear (Takım aşınması üzerine literatür çalışmaları)

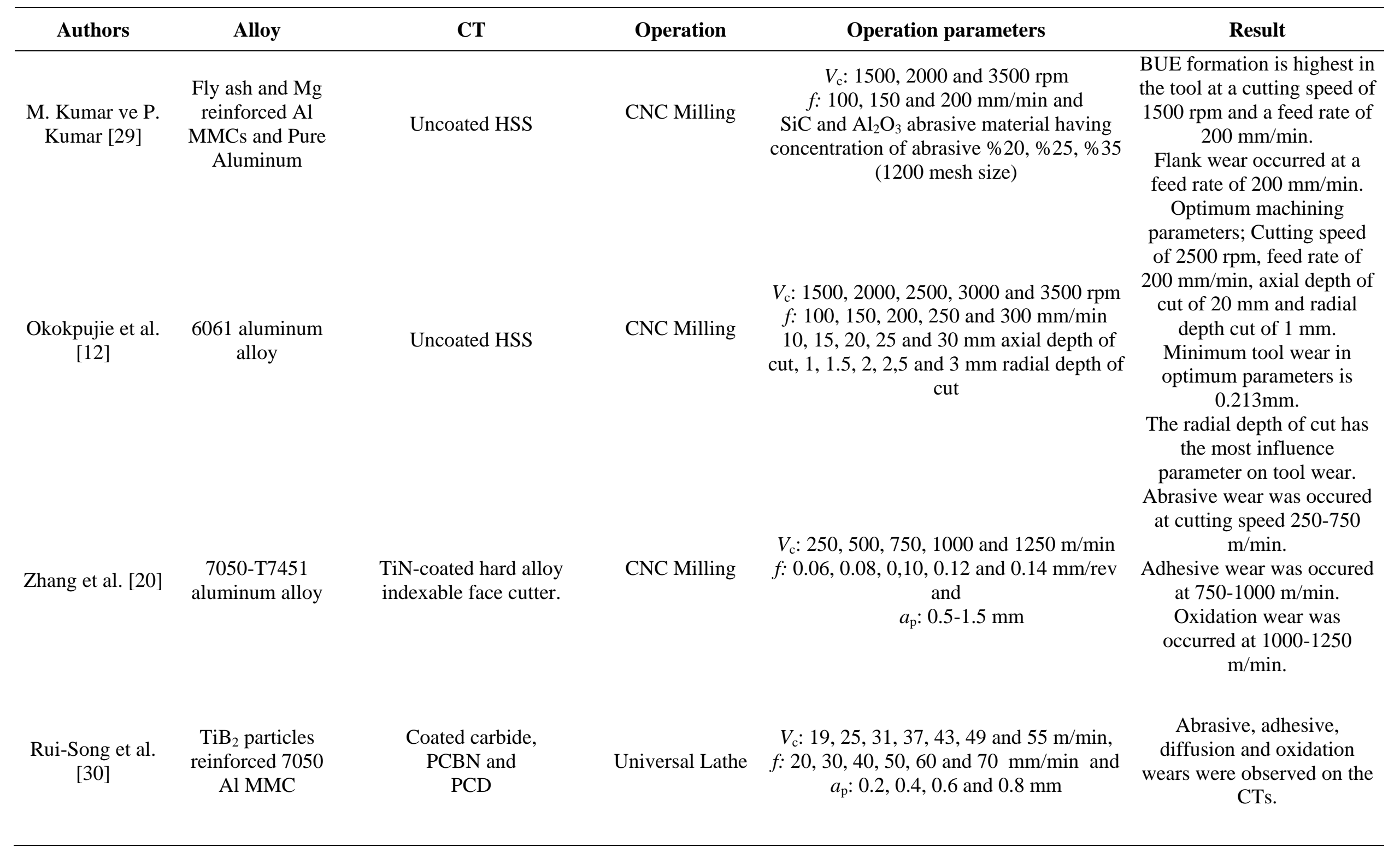




\begin{tabular}{|c|c|c|c|c|c|}
\hline Authors & Alloy & CT & Operation & Operation parameters & Result \\
\hline $\begin{array}{c}\text { Pattnaik et al. } \\
\text { [31] }\end{array}$ & $\begin{array}{l}\% 100 \text { Rolled } \\
\text { aluminum }\end{array}$ & $\begin{array}{c}\text { WC SPUN, } \\
\text { WC SPGN, } \\
\text { WC+TiN, } \\
\mathrm{WC}+\mathrm{Ti}(\mathrm{C}, \mathrm{N})+\mathrm{Al}_{2} \mathrm{O}_{3} \text { and } \\
\mathrm{PCD}\end{array}$ & CNC Lathe & $\begin{array}{c}V_{\mathrm{c}}: 336,426 \text { and } 540 \mathrm{~m} / \mathrm{min} \\
f: 0.045,0.06 \text { and } 0.09 \mathrm{~mm} / \mathrm{rev} \text { and } \\
a_{\mathrm{p}}: 2 \mathrm{~mm}\end{array}$ & $\begin{array}{l}\text { The least tool wear was } \\
\text { observed in PCD and WC } \\
\text { SPGN tools. }\end{array}$ \\
\hline $\begin{array}{c}\text { Muharrem Pul } \\
\text { [32] }\end{array}$ & $\begin{array}{c}7075,2024 \text { and } \\
6061 \text { aluminum } \\
\text { alloy }\end{array}$ & Uncoated cemented carbide & CNC Lathe & $\begin{array}{c}V_{\mathrm{c}}: 200,250,325 \text { and } 400 \mathrm{~m} / \mathrm{min} \\
f: 0.250,0.350 \text { and } 0.400 \mathrm{~mm} / \mathrm{rev} \text { and } \\
a_{\mathrm{p}}: 2.5 \mathrm{~mm}\end{array}$ & $\begin{array}{l}\text { Al } 2024 \text { alloy exhibited } \\
\text { performance more better } \\
\text { than the other alloys. }\end{array}$ \\
\hline Bican et al. [33] & $\begin{array}{l}\text { 2024, } 6061 \text { and } \\
7075 \text { aluminum } \\
\text { alloy }\end{array}$ & $\begin{array}{l}\text { CVD-(TiCN/Al2O3/TiN) } \\
\text { coated }\end{array}$ & CNC Lathe & $\begin{array}{c}V_{\mathrm{c}}: 40,60,80 \text { and } 120 \mathrm{~m} / \mathrm{min} \\
f: 0.3 \mathrm{~mm} / \mathrm{rev} \text { and } \mathrm{mm}\end{array}$ & $\begin{array}{l}\text { The highest BUE formation } \\
\text { was observed in machining } \\
\text { of } 2024 \text { aluminum alloy. } \\
\text { BUL rates in machining of } \\
2024 \text { and } 6061 \text { aluminum } \\
\text { alloys was higher than } 7075 \\
\text { aluminium alloy. }\end{array}$ \\
\hline
\end{tabular}

* Sorumlu yazarin e-posta adresi: cem.alparslan@erdogan.edu.tr

https://doi.org/10.52795/mateca.1008145 


\section{CONCLUSIONS (SONUÇLAR)}

In this study, current studies on tool wear during machining of aluminum-based alloys were investigated and these studies were presented in a comparative way. It was determined that aluminum-based alloys were generally produced as cast and wrought in industrial applications. It was demonstrated that the machinability of wrought alloys was excellent and the machinability of cast alloys could be developed by adding various alloying elements. While $V_{\mathrm{c}}, f$ and $a_{\mathrm{p}}$ were used as machinability input parameters or independent variables, Fc, $\mathrm{Ra}$ and tool wear were examined as output or dependent variables. The main forms of wear was generally identified as tool tip cracking and coating peeling for wrought aluminum alloys. It was revealed that the wear mechanisms were adhesive and abrasive wear. It was observed that the type of wear occurring in the tools used in the machining of such alloys was BUE. It revealed that BUE formation could be reduced by a combination of high $V c$, low $f$ and $a_{p}$. It was found that the surface quality of wrought aluminum was better than cast aluminum alloys during machining. It was observed that alloying elements had an effect on the machining properties of cast aluminum alloys. Among these elements, it was determined that $\mathrm{Zn}$ and $\mathrm{Cu}$ improve the machinability of alloys due to their lubricating effects. Although it improved the castability and mechanical properties of the alloys, it was shown that the addition of $\mathrm{Si}$ worst the machinability due to its abrasive feature. It was determined that BUE and BUL formations occurred in CTs in the machining of these alloys.

As a result of this study, it was revealed that the F, Ra, BUE and BUL formation decreased with the increasing of $V_{\mathrm{c}}$ in machining of aluminium alloys, while it increased with the increasing of $f$. It was determined that a combination of high $V_{\mathrm{c}}$ and low $f$ should be selected as optimum cutting conditions. In future studies, the effects of elemental additions such as Chromium, Manganese and Nickel on tool wear can be investigated in detail in terms of both wrought and casting techniques. Optimum cutting conditions during cutting tests can be determined by methods such as Taguchi, Gray relational analysis (GRA), ANN (Artificial neural network) and ANOVA (Analysis of variance). In addition, alternatives in machining theory can be ranked by multi-criteria decision techniques such as TOPSIS (Technique for Order Preference by Similarity to Ideal Solution), ELECTREE (ELimination Et Choix Traduisant la REalité), AHP (Analytic Hierarchy Process), VIKOR (Visekriterijumsko Kompromisno Rangiranje) and COPRAS (Complex Proportional Assessment).

\section{REFERENCES (KAYNAKLAR)}

1. G. Wittbecker, Aluminium Market Outlook, CRU Group, London, UK, 2018.

2. M.C. Santos, A.R. Machado, W.F. Sales, M.A. Barrozo, E.O. Ezugwu, Machining of aluminum alloys: a review, The International Journal of Advanced Manufacturing Technology, 86(9-12): 3067-3080, 2016.

3. Q. Luo, G. Robinson, M. Pittman, M. Howarth, W. M. Sim, M. R. Stalley, H. Leitner, R. Ebner, D. Caliskanoglu, P. E. Hovsepian, Performance of nano-structured multilayer PVD coating TiAlN/VN in dry high speed milling of aerospace aluminium 7010-T7651, Surf. Coatings Technology, 200: 123-127, 2005.

4. H. Demir, S. Gündüz, The effects of aging on machinability of 6061 aluminium alloy, J Materials and Design, 30(5): 1480-1483, 2009.

5. P. E. Hovsepian, Q. Luo, G. Robinson, M. Pittman, M. Howarth, D. Doerwald, R. Tietema, W. M. Sim, A. Deeming, T. Zeus, TiAlN/VN superlattice structured PVD coatings: a new alternative in machining of aluminium alloys for aerospace and automotive components, Surf Coat Technol, 201(1-2): 265-272, 2006.

6. I. Zagórski \& T. Warda, Effect of technological parameters on the surface roughness of aluminium alloys after turning, Advances in Science and Technology Research Journal, 12(2): 144-149, 2018.

7. A. Gomaz-Parra, M. Alvarez-Alcon, J. Salguero, M. Batista, M. Marcos, Analysis of the evolution of the built-up edge and built-up layer formation mechanisms in the dry turning of aeronautical aluminium alloys, Wear, 302: 1209-1218, 2013.

\footnotetext{
* Sorumlu yazarin e-posta adresi: cem.alparslan@erdogan.edu.tr

https://doi.org/10.52795/mateca.1008145
} 
8. A. Manna, B. Bhattacharya, Influence of machining parameters on the machinability of particulate reinforced Al/SiC-MMC, Int. J. Adv. Manuf. Technology, 25: 850-856, 2005.

9. R. K. Bhushan, S. Kumar, S. Das, Effect of machining parameters on surface roughness and tool wear for $7075 \mathrm{Al}$ alloy SiC composite, Int. J. Adv. Manuf. Technology, 50:459-469, 2010.

10. P. Roy, S. K. Sarangi, A. Ghosh, A. K. Chattopadhyay, Machinability study of pure aluminum and Al$12 \% \mathrm{Si}$ alloys against uncoated and coated carbide inserts, Int. Journal of Refractory Metals \& Hard Materials, 27: 535-544, 2009.

11. A. Rivero, G. Aramendi, S. Herranz, L. N. Lopez de Lacalle, An experimental investigation of the effect of coatings and cutting parameters on the dry drilling performance of aluminium alloys, Int $\mathbf{J}$ Adv Manuf Technol, 28: 1-11, 2006.

12. I.P. Okokpujie, O.M. Ikumapayi, U.C. Okonkwo, E.Y. Salawu, S.A. Afolalu, J.O. Dirisu \& O.O. Ajayi, Experimental and Mathematical Modeling for Prediction of Tool Wear on the Machining of Aluminium 6061 Alloy by High Speed Steel Tools, Open Engineering, 7(1): 461-469, 2017.

13. M. P. Groover, Fundamentals of modern manufacturing, 4th ed., John wiley\& Sons,Inc, USA, 1999.

14. A. R. Machado, Machining of Ti6Al4V and Inconel 901 with a High pressure coolant system, Ph.D. Thesis, University of Warwick, Coventry, England, 1990.

15. G. List, M. Nouari, D. G' ehin, S. Gomez, J. P. Manaud, Y. Le Petitcorps, F. Girot, Wear behavior of cemented carbide tools in dry machining of aluminium alloy, Wear 259: 1177- 1189, 2005.

16. A. R. Machado, J. Wallbank, Machining of titanium and its alloys - a review, Proc. of the Inst. Mech. Eng. J. Eng. Manufacture, I IMECHE, London, England, Part B 204: 53-60, 1990.

17. C. A. Anderson, G. Milan, M. B. Silva, A. R. Machado, Some observations on wear and damages in cemented carbide tools, J. of the Braz. Soc. Of Mech. Sci. \& Eng, 28(3): 269-277, 2006.

18.Sandvik Coromant, Wear on cutting edges, https://www.sandvik.coromant.com/tr tr/knowledge/materials/pages/wear-on-cutting-edges.aspx, 05.03.2021.

19.V. Songmene, R. Khettabi, I. Zaghbani, J. Kouam, \& A. Djebara, Machining and machinability of aluminum alloys. Alum. Alloys Theory Appl, 377-400, 2011.

20. Z. Ping, Y. Xiujie, W. Penghao, Y. Xiao, Surface integrity and tool wear mechanism of 7050-T7451 aluminum alloy under dry cutting, Elsevier Vacuum, 184: 1-12, 2021.

21. P. Gao, X. Wang, Z. Liang, J. Xiang, W. Li, J. Xie, Effects of WC grain size and Co content on microscale wear behavior of micro end mills in aluminum alloy 7075 machining, The International Journal of Advanced Manufacturing Technology, 104: 2401-2413, 2019.

22. W. H. Wang, X. Cheng, O. L. Sun, F. Wang, X. M. Yang, Study on tool wear for mircomilling of 6061 aluminium alloy, The 2nd International Workshop on Materials Science and Mechanical Engineering 504, 2019.

23. Z. Ping, Z. Xiancheng, C. Xian, Y. Xiao, W. Youqiang, Analysis on the tool wear behavior of 7050T7451 aluminum alloy under ultrasonic elliptical vibration cutting, Elsevier Wear, 466-467, 2021.

24.Ş. Bayraktar, F. Afyon, Machinability properties of $\mathrm{Al}-7 \mathrm{Si}, \mathrm{Al}-7 \mathrm{Si}-4 \mathrm{Zn}$ and $\mathrm{Al}-7 \mathrm{Si}-4 \mathrm{Zn}-3 \mathrm{Cu}$ alloys, Journal of the Brazilian Society of Mechanical Sciences and Engineering, 42: 187, 2020.

25. A. P. Hekimoğlu, Ş. Bayraktar, Y. Turgut, Investigation of Effect of Cutting Speed and Feed Rate on Machining of the Al-35Zn Alloy, 2nd International Symposium on Innovative Approaches in Scientific Studied, November 30- December 2 2018, Samsun, Turkey.

26. Ş. Bayraktar, Ç. Çamkerten, N. Salihoğlu, Investigation of the Effect on Copper and Silicon Additives on Machinability in Turning of Al-25Zn Alloy with CVD-Al2O3 Coated Tools, GU J Sci, Part C, 8(1): 7993, 2020.

27. R. Ghoreishi, A. H. Roohi, A. D. Ghadikolaei, Evaluation of tool wear in high-speed face milling of $\mathrm{Al} / \mathrm{SiC}$ metal matrix composites, Journal of the Brazilian Society of Mechanical Sciences and Engineering, 41: 146, 2019.

28. M. Pul, Investigation of effects of $\mathrm{MgO}$ ratio on the surface quality and tool wear in turning $\mathrm{Al}-\mathrm{MgO}$ composites, Proc IMechE Part B: J Engineering Manufacture 1-10, 2017.

29. M. Kumar, P. Kumar, Experimental investigations on tool wear during abrasive assisted drilling of aluminum matrix composite using anova, Optimization in Engineering Research, 1(2): 40-54, 2020.

30. J. Rui-Song, W. Wen-hu, S. Guo-dong and W. Zeng-qiang, Experimental investigation on machinability of in situ formed TiB2 particles reinforced Al MMCs, Journal of manufacturing processes, 23: 249-257, 2016.

\footnotetext{
* Sorumlu yazarin e-posta adresi: cem.alparslan@erdogan.edu.tr

https://doi.org/10.52795/mateca.1008145
} 
31. S. K. Pattnaik, N. K. Bhoi, S. Padhi, S. K. Sarangi, Dry machining of aluminum for proper selection of cutting tool: tool performance and tool wear, The International Journal of Advanced Manufacturing Technology, 98(1-4): 55-65, 2018.

32. M. Pul, Comparison of surface roughness and tool wear in turning of 7075, 6061 and 2024 aluminum alloys, International Journal of Engineering Research and Development, 9(2): 65-75, 2012.

33. O. Bican, M. Pul, Comparison of the effect of alloy type on some machining properties in turning different aluminum alloys, Journal of Engineering Sciences And Researches, 3(1): 9-17, 2021.

34. A. K. Sahoo, S. Pradhan, Modeling and optimization of Al/SiCp MMC machining using Taguchi approach, Measurement, 46(9): 3064-3072, 2013. 